\title{
DISCONTINUITY SURFACES OF POSSIBLE MICROKARST ORIGIN IN THE VIIVIKONNA FORMATION (KUKRUSE STAGE, MIDDLE ORDOVICIAN) OF ESTONIA
}

Discontinuity surfaces (DS) are now widely recognized in ancient sediments. In the Ordovician of Baltoscandia they are described by several authors (e. g. Orviku, 1940; review by Jaanusson, 1961; Lindström, 1963, 1979; Holmer, 1983). The origin of DS has been ascribed to either subaerial exposure or submarine agencies. Jaanusson (1973), Larsson (1973) and Holmer (1983) have given evidence to indicate that in Baltoscandia at times during the Middle Ordovician the sea was very shallow indeed, and the seafloor became exposed occasionally.

The purpose of this paper is to describe two DS encountered in the Viivikonna Formation that display well-developed microkarst-like features and to interpret the environmental conditions of their formation. The applied terminology is the same as proposed by Bromley (1975) and Fürsich (1979).

The lower Middle Ordovician Viivikonna Formation corresponds to the Kukruse Stage. which approximately coincides with the Nemagraptus gracilis Zone (Мянниль, 1986). It consists of frequently alternating oil shale (kukersite), kerogenous limestone, and argillaceous limestone beds. The areal extent of the Viivikonna Formation is restricted to the northern part of Estonia and the westernmost part of the Leningrad district. The kukersite deposition took place at the northern margin of the shallow carbonate shelf bordering the Fennosarmatian lowland (Puura et al., 1988). The Baltoscandian epicontinental sea was at that time probably situated in the temperate climatic zone as indicated by sedimentological evidence (Jaanusson, 1973) and shown also on some palaeomagnetically based Ordovician world map reconstructions (Noltimier, Bergström, 1976; Ziegler et al., 1979).

From sedimentological viewpoint it is of interest that the kukersite accumulation zone was bounded by the extensive non-sedimentation area from the north (Fig. 1). In the sedimentary record it is recognizable as a vast hardground belt. Unfortunately the real position of the Fennosarmatian shoreline is unknown because: 1) neither beach nor tidal flat deposits are recorded in the Viivikonna Formation; 2) the most onshore sediments are partly destroyed by post-Devonian erosion.

The sediments of the Viivikonna Formation comprising organic matter accumulated during the prominent and prolonged late Llandeilian-early Caradocian regression (Puura et al., 1988) and are characterized by a sedimentation of interruptive nature. In the sedimentary succession a lot of DS have been recorded. In the most condensed sections (NW Estonia) their number may reach 35 . DS are related both to kukersite seams and limestone beds, but occur mainly on the upper surfaces of kukersite seams, and are traceable over a wide area covering hundreds of square kilometers. Most of them are slightly undulating and have smooth or micro- 
scopically irregular morphology with a thin pyritized or phosphatized impregnation zone. These surfaces are evidently of submarine origin. However, two surfaces, described below, display highly irregular relief that seems to be of microkarst origin.

\section{Description of DS}

The first studied surface rests at the top of kukersite seam III in the upper part of the Kukruse Stage. It has been recorded in nearly all the cores in the investigated area (Fig. 1). This DS in the northern and central parts of the occurrence is usually intensely bioturbated and has an indistinct, occasionally pyritized impregnation zone. It is remarkable that the pyritized impregnation substitutes for a phosphatic one to the southern direction (basinwards). The phosphatic impregnation zone is observed only in argillaceous limestone facies with very low organic matter content (Fig. 1, Jõgeva boring).

In the western part of Estonia (including islands) a particular DS is found at the same level. This surface is characterized by a network of rather narrow $(1-3 \mathrm{~cm}$ ) and deep (up to $20 \mathrm{~cm}$ ) subvertical cavities (Plate I, figs $1-3$ ). These cavities are eroded into buff-grey, slightly kerogenous calcarenitic limestone that composes the rock in the western marginal part of kukersite seam III. On the walls of cavities rather thick (up to $5 \mathrm{~mm}$ ) encrustations of pyrite are observable, while at the top of ridges the impregnation zone is quite thin. The cavities between ridges are filled by grey calcilutite or buff-grey kerogenous calcilutite. Inside cavity fillings, at least three generations of burrow systems are recognized. Rare straight to gently curved borings of ichnogenus Trypanites are present on the ridges (Plate I, figs 1,2 ), indicating that the surface was lithified to the hardground stage of its development. No evidence for the presence of an encrusting epizoan fauna has been found. Sometimes it can be observed how two or three DS merge together at this level (Plate I, fig. 3).

This DS or a set of merged DS correspond to an appreciable break in the sedimentary succession as overlying limestone bed between kukersite seams III and IV is missing or preserved only as cavity fillings. The area where this limestone bed was not deposited or was subsequently eroded roughly coincides with the karstified area. In the western part of Estonia it has rather wide extent (probably up to some thousand square kilometers).

The other peculiar DS is formed at the top of the kukersite seam $K_{1}$ (Fig. 1), where a labyrinth of pits and subrounded ridges have developed on the upper surface of light-brown bioturbated kerogenous skeletal calcarenite. These pits vary in width and depth but do not exceed $5 \mathrm{~cm}$ across and $8 \mathrm{~cm}$ deep. The clear impregnation zone is absent, but the contact with overlying grey calcilutite (which also fills pits) is rather smooth and very sharp. The surface was formed at the firmground stage of sediment lithification as indicated by the overhanging walls of pits.

Fig. 1. Facial sketch-maps for kukersite seams III and $\mathrm{K}_{1}$ with type sections. 1 - kukersite with nodules of kerogen-rich limestone; 2 - kerogen-rich limestone with thin wavy kukersite layers; 3 - kerogen-poor limestone with thin kukersite layers and lenses; 4 - limestone with thin kukersite layers and lenses; 5 - grey pure limestone; 6 - grey, slightly argillaceous limestone; 7 - greenish-grey medium-argillaceous limestone; 8 non-deposition area (hardground); 9 - recent erosion boundary of the Kukruse Stage; 10 - boundary of karstified area; 11 - facies boundaries; 12 - discontinuity surfaces ( $a$ - pyritized, $b$ - phosphatized or unimpregnated); 13 - isopach, $\mathrm{m}$. 

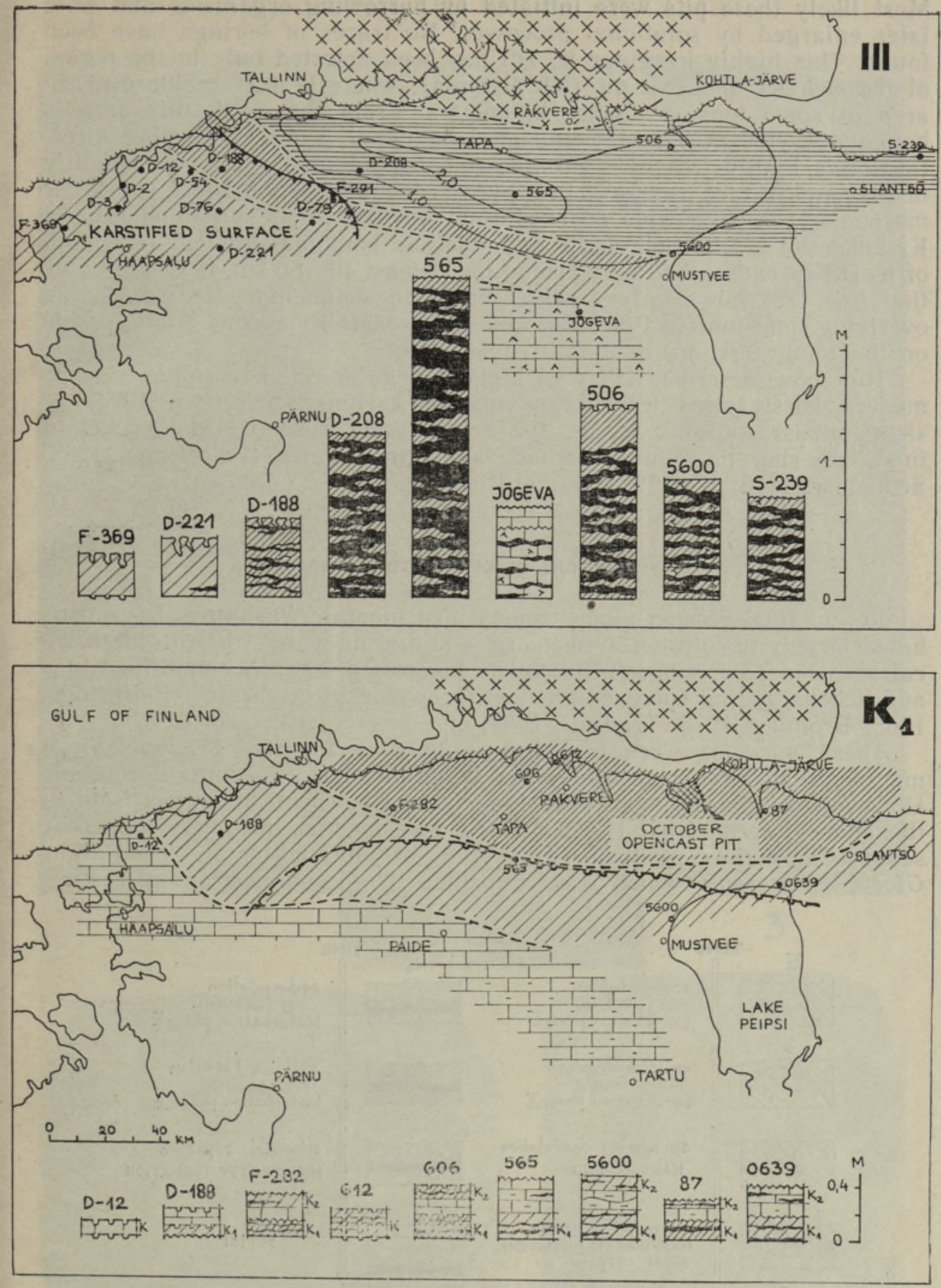

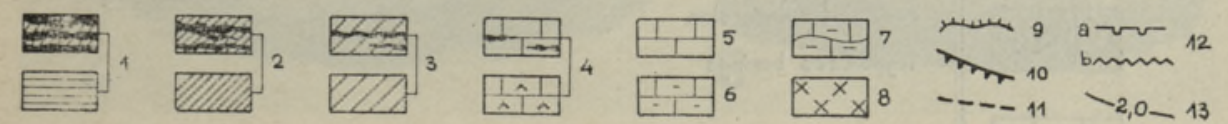


Most likely these pits were initiated by burrowing organisms and were later enlarged by solutional processes. No traces of borings have been found. This highly irregular $K_{1}$ DS has been detected only in the region of the October opencast pit (NE Estonia), where it is traceable over an area of some tens of square kilometers. From the north this area is bounded by the present-day erosional boundary, whereas to other directions this highly irregular DS passes laterally into a wavy or slightly undulating surface having a thin pyritized impregnation zone. The latter morphology is observable nearly throughout the whole spreading area of $K_{1}$ kukersite seam. Judging from numerous boreholes studied the width of $K_{1}$ DS spreading belt may extend for at least $40-60 \mathrm{~km}$. It is noticeable that this DS shows only a minor break in sedimentary record, as the overlying limestone bed between kukersite seams $K_{1}$ and $K_{2}$ is observable on the whole territory of the oil shale basin.

The above-described DS with highly irregular relief resemble to some modern karst forms termed as «marine karren» (Sweeting, 1973) or «kamenitzas» (Kobluk et al., 1977, 1984) and observed along modern limestone shorelines in the splash and spray zones (Fairbridge, 1968; Schneider, 1976; Ley, 1979; Trudgill, 1987).

\section{Development of coastal microkarst}

Recent tidal erosion along tropical to temperate coasts has been attributed largely to solution by meteoric and marine waters than to mechanical abrasion (Sweeting, 1973) and to bioerosion, e. g. by endolithic algae and lichens, boring sponges, bivalves, browsing invertebrates (Fairbridge, 1968; Bromley, 1975; Trudgill, 1987).

These agencies were probably responsible for the development of microkarst surfaces in the lower Middle Ordovician Viivikonna Formation. However, of special importance may be the biochemical factor. Both of the above-described karstified DS are developed at the top of kukersite seams. The main constituent of kukersite organic matter are fossil algae Gloeocapsamorpha, which was confirmed by recent electron microscope

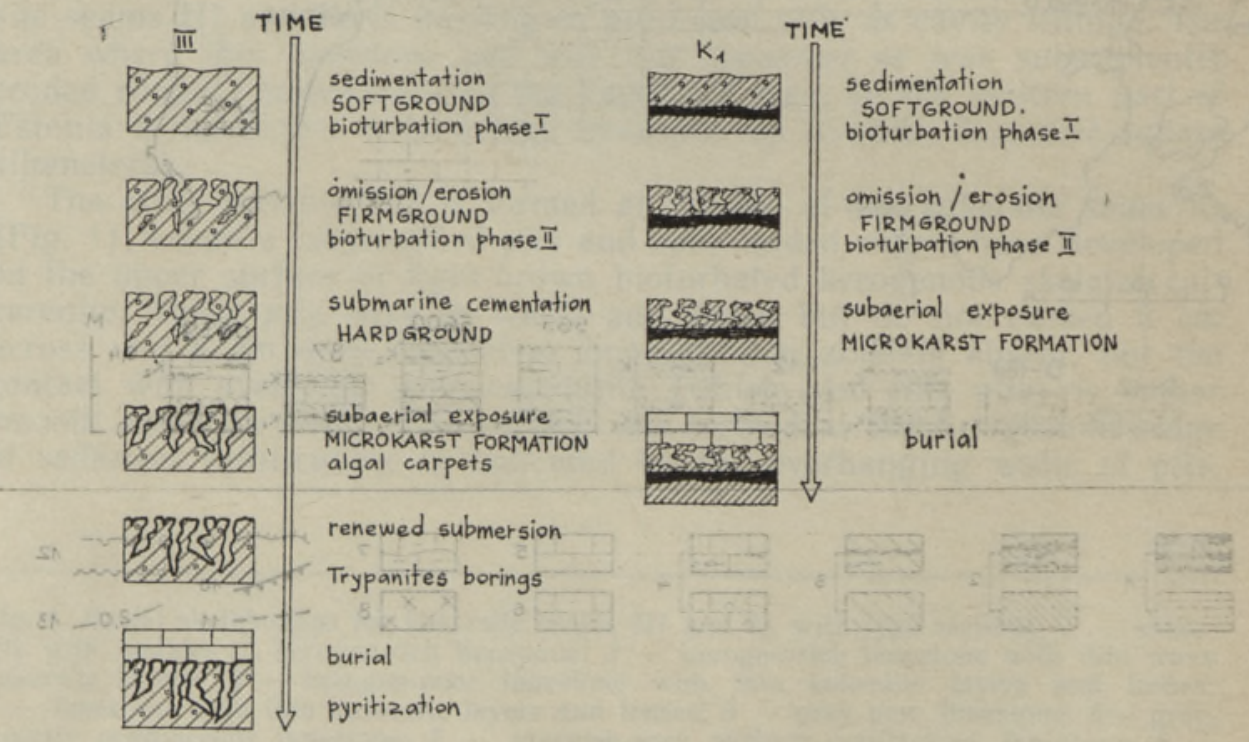

Fig. 2. Sequence of events in the development of microkarst at the top of kukersite seams III and $K_{1}$. For legend see Fig. 1. 

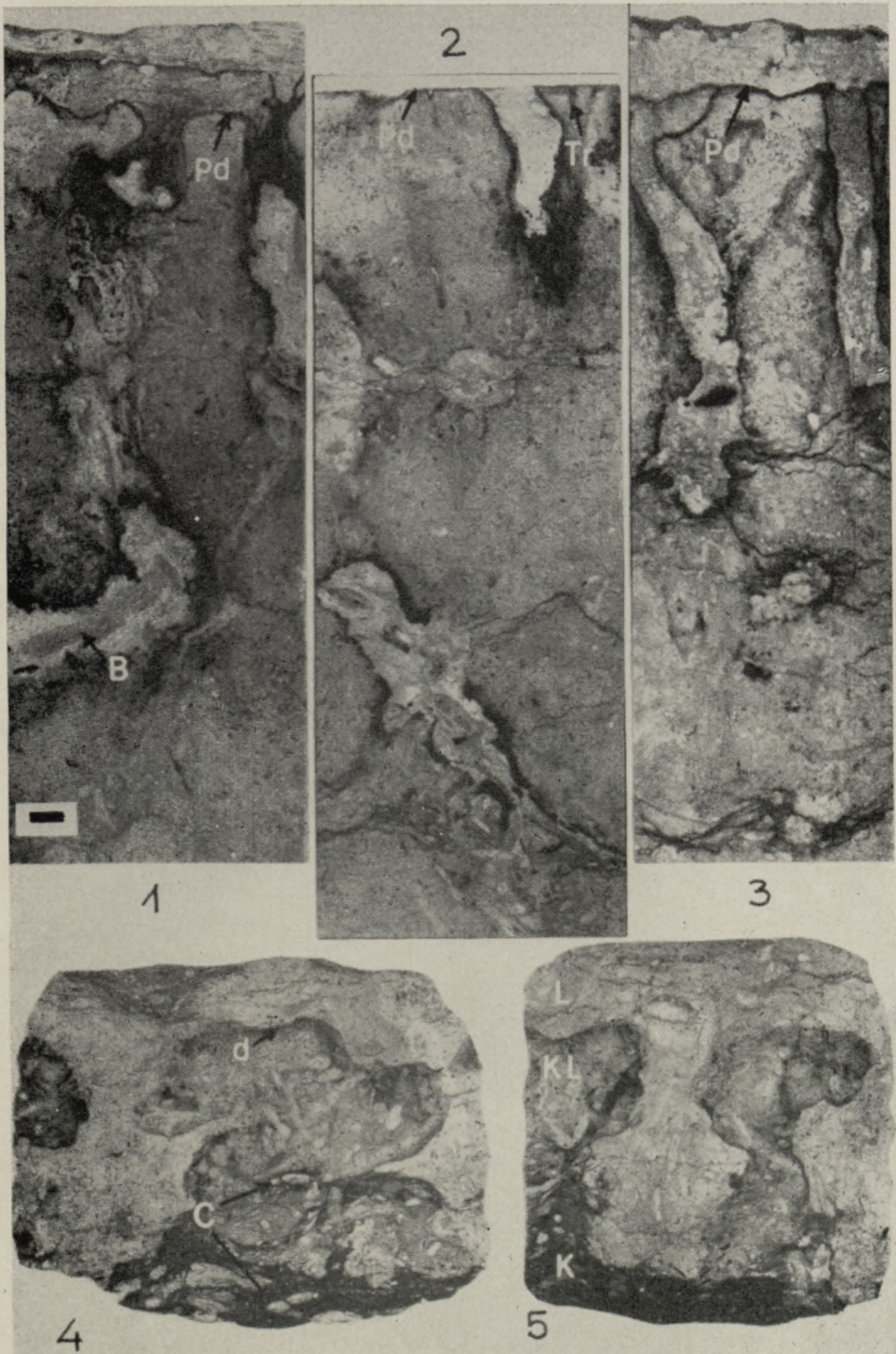

Figs $1-3$. Karstified surface at the top of kukersite seam III, showing pyritized impregnation zone (Pd), small Trypanites borings ( $\mathrm{Tr})$ and burrow systems inside cavity fillings (B). Boreholes: D-221 (1), D-76 (2), and D-79 (3).

Figs 4-5. Vertical profile of the $K_{1}$ karstified suriace ( $K-$ kukersite, $K L-$ kerogenous limestone, L - grey limestone) in the October opencast pit; $d$ indicates the unimpregnated discontinuity surface, and $C$ shows Chondrites burrows. Scale bar for all the figures $10 \mathrm{~mm}$. 



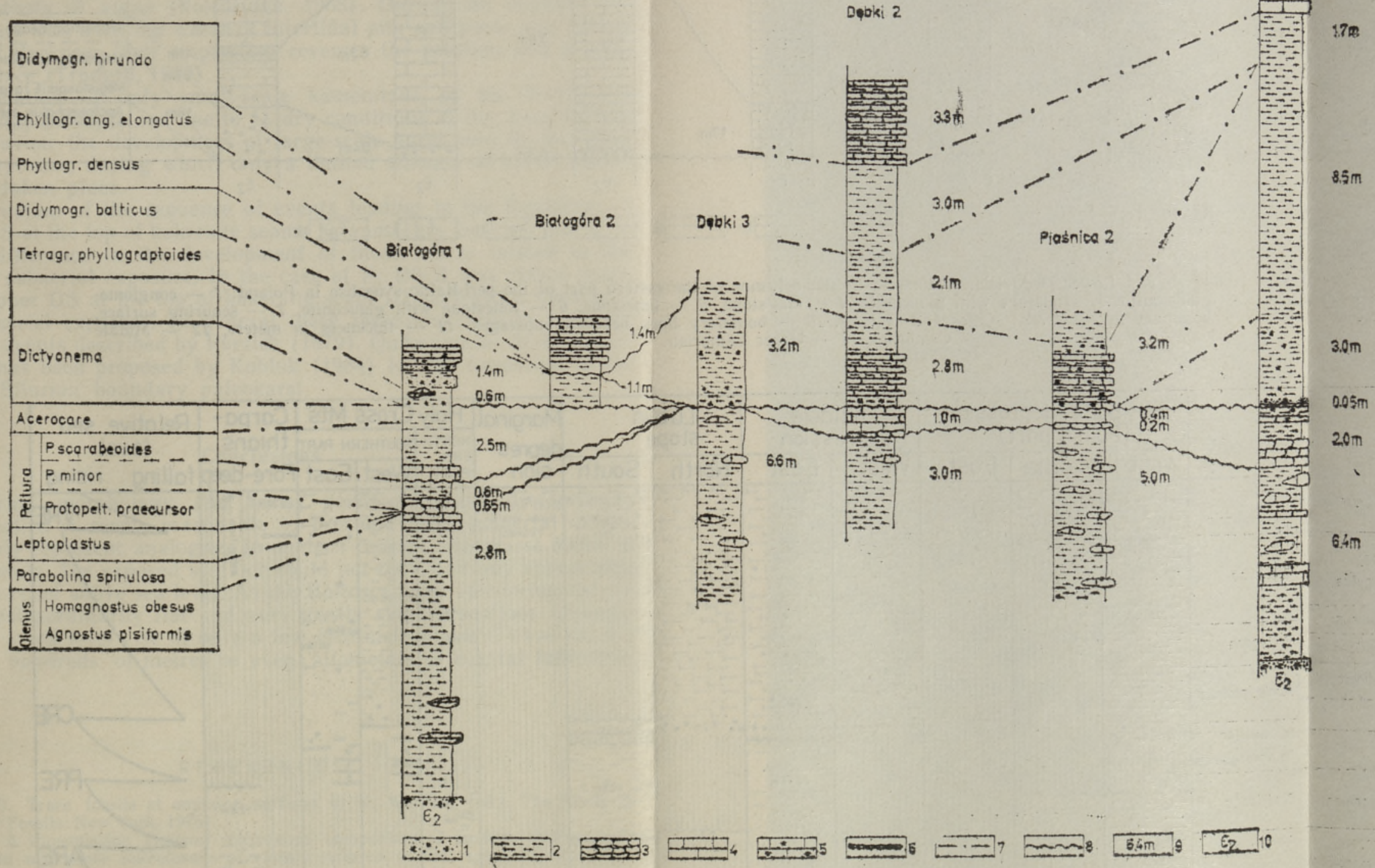

Fig. 2. Correlation of Cambrian and Lower Ordovician sediments in the columns of the Leba area (western part of the peri-Baltic syneclise in Poland):

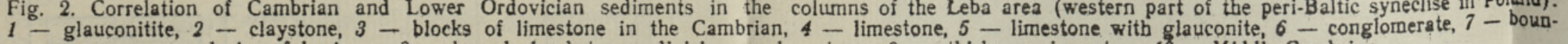
daries of horizons, 8 - boundaries between divisions and systems, 9 - thickness in meters, 18 - Middle Cambrian. 


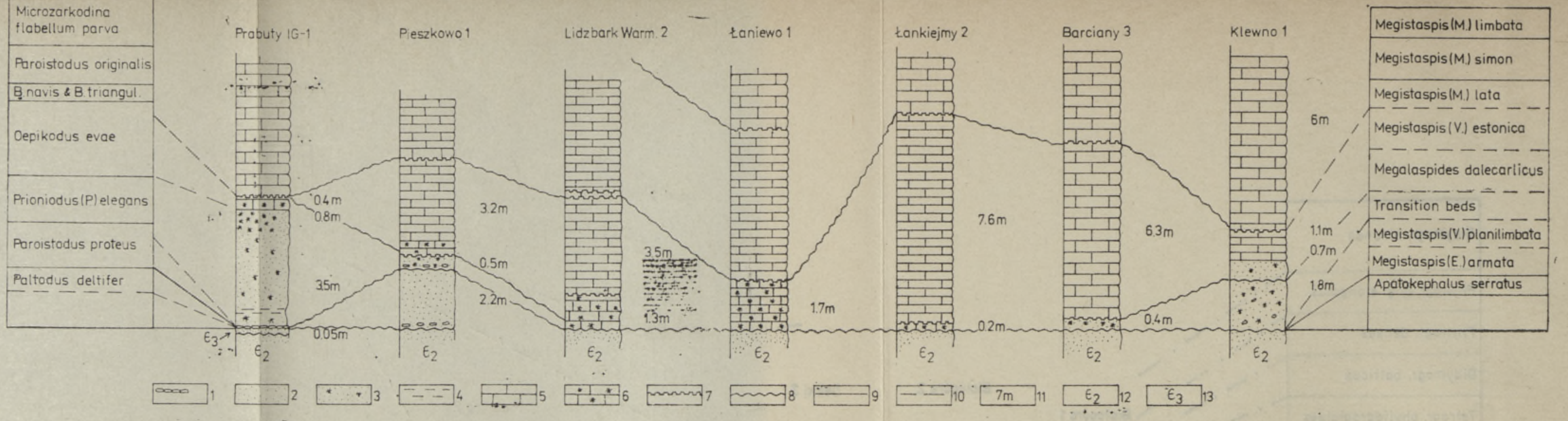

Fig. 3. Correlation of Cambrian and Lower Ordovician sediments in the columns of the eastern part of the peri-Baltic syneclise in Poland: $1-$ conglomerate, 2 - sandstone, 3 - glauconitite or sandstone with glauconite, $4-$ clay stonè, 5 - limestone, 6 - limestone with glauconite, $7-$ scouring surface,
8 - erosion surface, 9 - boundary lines between stages and systems, $10-$ boundary lines between substages, $11-$ thickness in meters, $12-$ Middle

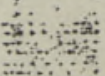

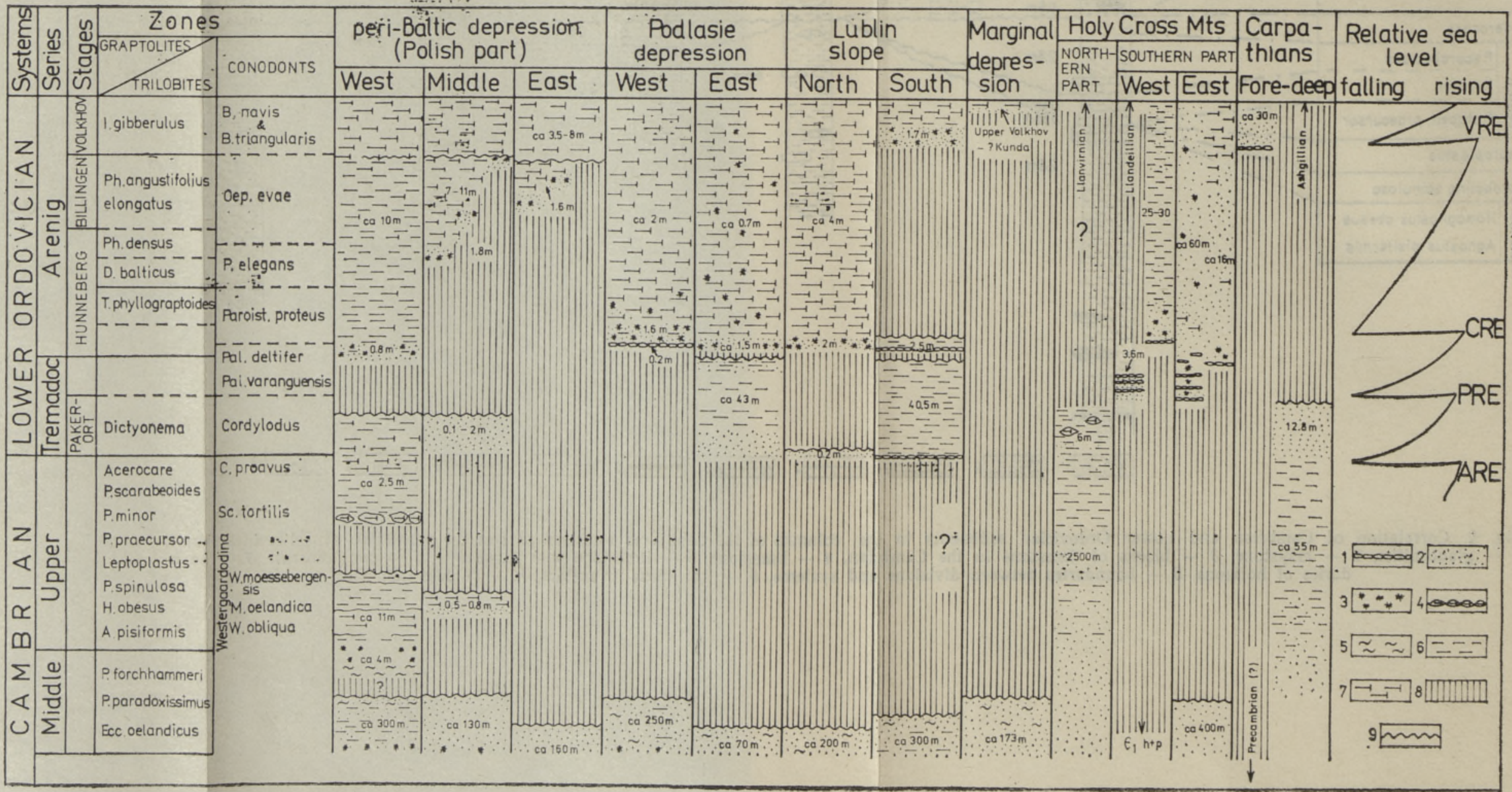

Fig. 4. Stratigraphic scheme of the Cambrian-Ordovician boundary beds in Poland: 1 - conglomerate, $2-$ sandstone, 3 - glauconite, 4 - blocks of limestone in the Cambrian, 5 - mudstone, 6 - claystone, 7 - marly limestone, 8 - gap, 9 - erosion surfaces. 
studies (Burns, 1982). The development of microkamenitzas on the upper surfaces may have been aided by organic matter accumulating in the pits. During the decay of the organic matter the acidity of water rises and thereby it favours solutional processes. In the intertidal zone enlargement of pits and formation of undercut surfaces is caused also by photosynthetic activity of algae (Fairbridge, 1968). During the daylight the algae abstract $\mathrm{CO}_{2}$ from the water of intertidal pits and pools and during the hours of darkness their respiration reverses the reaction and a solution takes place (Trudgill, 1987).

The formation of only small-scale kamenitzas in the Viivikonna Formation may be explained due to 1) dry conditions of low rainfall that would not favour the development of large-scale karst, and 2) the short period of exposure, during which only a limited amount of karstification could have taken place.

Reconstruction of the sequence of events leading to the formation of karstified DS at the top of kukersite seams $K_{1}$ and III is depicted in Fig. 2. The main difference in the development of these DS is related to the duration of subaerial exposure. In the case of $K_{1}$ DS it was rather short, while the upper DS at the top of kukersite seam III survived a more prolonged subaerial exposure. In general these reconstructions fit with the sequence of events described by Fürsich (1979). Quite similar development succession has been proposed by Kobluk (1984) for the formation of the Ordovician-Silurian boundary paleokarst.

\section{Conclusions}

Considering morphology and facial position of the discontinuity surfaces studied it seems reasonable to presume their subaerial origin. They possibly represent analogues to modern coastal microkarst forms in temperate areas. The exposed seafloor could not have had any appreciable topographic relief above sea level. As the Baltoscandian epicontinental sea owned an extraordinarily flat and very gently sloping seafloor (Jaanusson, 1973), a sea level rise of only a few centimetres would have rapidly submerged hundreds of metres or even kilometers of coastal limestone.

\section{REFERENCES}

Bromley, R. G. Trace fossils at omission surfaces // R. W. Frey (ed.) The Study of Trace Fossils. New York, 1975.

Burns, D. A. A transmission electron microscope comparison of modern Botryococcus braunii with some microfossils previously referred to that species // Rev. Esp. Micropaleont., 1982, 14, 165-185.

Fairbridge, $R$. W. (ed.) The Encyclopedia of Geomorphology. New York-AmsterdamLondon, 1968.

Fürsich, F. T. Genesis, environments, and ecology of Jurassic hardgrounds // N. Jb. Geol. Abh., 1979, 158, 1-63.

Holmer, L. Lower Viruan discontinuity surfaces in central Sweden // Geol. Fören. Förhandl., 1983, 105, 29-42.

Jaanusson, V. Discontinuity surfaces in limestones // Bull. Geol. Inst. Uppsala, 1961, $40,221-241$

Jaanusson, $V$. Aspects of carbonate sedimentation in the Ordovician of Baltoscandia // Lethaia, 1973, 6, 11-34.

Kobluk, D. R. Coastal paleokarst near the Ordovician-Silurian boundary, Manitoulin Island, Ontario // Bull. Canadian Petrol. Geol., 1984, 32, 398-407.

Kobluk, D. R., Pemberton, S. G., Karolyi, M., Risk, M. J. The Silurian-Devonian disconformity in southern Ontario // Bull. Canadian Petrol. Geol., 1977, 25, 11571186.

Larsson, $K$. The Lower Viruan in the autochthonous Ordovician sequence of Jämtland // Sver. Geol. Unders., 1973, C 683, $1-82$. 
Ley, R. G. The development of marine Karren along the Bristol Channel coast line /I Z. Geomorphol., Suppl., 1979, 32, 75-89.

Lindström, M. Sedimentary folds and the development of limestone in an Early Ordovician sea // Sedimentology, 1963, 2, 243-292.

Lindström, M. Diagenesis of Lower Ordovician hardgrounds in Sweden // Geol. et Palaeont., 1979, 13, 9-30.

Noltimier, H. C., Bergström, S. M. Paleomagnetic studies of Early and Middle Ordovician limestones from the Baltic Shield // Geol. Soc. Amer. Abstr. Progr. 8, $1976,4,501$.

Orviku, $K$. Lithologie der Tallinna-Serie (Ordovizium, Estland), I // Acta et Comm. Univ. Tartuensis, 1940, A 36, 3-249.

Puura, V., Bauert, H., Männil, R. The conditions of kukersite deposition // Proc. Int. Conf. on Oil Shale and Shale Oil. Beijing, May 16-19, 1988, 42-50.

Schneider, J. Biological and inorganic factors in the destruction of limestone coasts. Contributions to Sedimentology N 6. Stuttgart, 1976.

Sweeting, M. M. Karst Landforms. London, 1973.

Trudgill, S. T. Bioerosion of intertidal limestone, Co. Clare, Eire. 3. Zonations, process and form // Mar. Geol., 1987, 74, 111-121.

Ziegler, A. M., Scotese, C. R., McKerrow, W. S., Johnson, M. E., Bambach, R. K. Paleozoic paleogeography // Annu. Rev. Earth Planet. Sci., 1979, 7, 473-502.

Мянниль $P$. Стратиграфия кукерситоносных отложений $\mathrm{C}_{1} \mathrm{~b}-\mathrm{C}_{11} / /$ Строение сланценосной толщи Прибалтийского бассейна горючих сланцев-кукерситов. Таллин, $1986,12-24$.
Academy of Sciences of the Estonian SSR, Institute of Geology
Received
Jan. 4,1989

\section{H. BAUERT \\ VOIMALIKEST KARSTUMISNÄHTUSTEST VIIVIKONNA KIHISTU
(KUKRUSE LADE) SETTEKATKESTUSPINDADEL EESTIS}

On kirjeldatud Balti põlevkivibasseinis III ja $K_{1}$ põlevkivikihi laes esinevate settekatkestuspindade morfoloogiat ja pindalalist levikut. Teatud piirkondades oma levikualal (Läăne-Eesti ja Oktoobri pōlevkivikarjäär) iseloomustab neid settekatkestuspindu tugevalt liigestunud reljeef, mis sarnaneb tänapäeva rannavööndis parasvöötme tingimustes kujunevate karstivormidega. On antud ülevaade karstumist pōhjustavatest teguritest ning esitatud võimalik mudel karstunud katkestuspindade kujunemisest ordoviitsiumi paleobasseinis.

\section{X. БАУЭРT}

\section{ПОВЕРХНОСТИ ПЕРЕРЫВА С ВОЗМОЖНЫМ СУБАЭРАЛЬНЫМ ПРОИСХОЖ- ДЕНИЕМ В ВИЙВИКОННАСКОЙ СВИТЕ (КУКРУЗЕСКИИ ГОРИЗОНТ, СРЕДНИИ ОРДОВИК) ЭСТОНИИ}

Описываются морфология и площадное распространение поверхностей перерыва, развитые в кровле пластов горючего сланца-кукерсита III и $\mathrm{K}_{\mathrm{I}}$ Западной Эстонии и разреза Октябрьский. Поверхности перерыва характеризуются резко неровным рельефом с многочисленными, относительно глубокими, узкими углублениями, которые напоминают микрокарстовые формы, образующнеся в береговых районах современных морей умеренного пояса. Описываются также вероятные факторы, вызывающие и способствующне эрозии и предлагается возможная модель формирования закарстованных поверхностей перерыва в ордовикском палеобассейне. 